\title{
Pengaruh Model Self Regulated Learning terhadap Hasil Belajar IPA Siswa
}

\author{
I Kadek Adhi Dharma Putra ${ }^{1 *}$, Ni Wayan Arini², I Komang Sudarma ${ }^{3}$ \\ ${ }^{12}$ Jurusan Pendidikan Guru Sekolah Dasar, FIP, Universitas Pendidikan Ganesha, Indonesia \\ 3 Jurusan TP, FIP, Universitas Pendidikan Ganesha, Indonesia
}

\author{
A R TICLEINFO \\ Article history: \\ Received 18 May 2019 \\ Received in revised form \\ 30 June 2019 \\ Accepted 15 July 2019 \\ Available online 25 August \\ 2019 \\ Kata Kunci: \\ Hasil Belajar, IPA, Self \\ Regulated Learning \\ Keywords: \\ IPA, Learning Outcomes, Self \\ Regulated Learning
}

\begin{abstract}
A B S T R A K
Penelitian ini bertujuan untuk mengetahui pengaruh model Self Regulated Learning terhadap hasil belajar IPA antara kelompok siswa yang dibelajarkan dengan model pembelajaran Self Regulated Learning dan kelompok siswa yang dibelajarkan dengan model pembelajaran konvensional. Penelitian ini adalah penelitian eksperimen semu dengan desain Non Equivalent Post-Test Only Control Group Design. Populasi penelitian ini adalah seluruh siswa kelas V di SD Gugus X Kabupaten Buleleng, yang berjumlah 163 siswa. Pengambilan sampel menggunakan teknik random sampling. Sampel penelitian yaitu kelompok siswa kelas $\mathrm{V}$ di SDN 2 Kaliuntu yang terpilih sebagai kelompok eksperimen dan SDN 3 Kaliuntu sebagai kelompok kontrol. Data hasil belajar siswa diperoleh melalui metode tes, yaitu tes pilihan ganda. Data yang diperoleh dianalisis menggunakan teknik analisis statistik deskriptif dan statistik inferensial uji-t polled varians. Hasil pengujian hipotesis menunjukkan bahwa terdapat perbedaan yang signifikan hasil belajar IPA antara kelompok siswa yang mengikuti pembelajaran dengan model Self Regulated Learning dan kelompok siswa yang mengikuti pembelajaran konvensional. Hasil pengujian diperoleh ( $\left.t_{\text {hitung }}=8,76>t_{\text {tabel }}=1,86\right)$ sehingga $H_{0}$ ditolak dan $H_{1}$ diterima. Dengan demikian, kelompok siswa yang dibelajarkan dengan model pembelajaran Self Regulated Learning menunjukkan hasil belajar yang lebih tinggi dibandingkan dengan kelompok siswa yang dibelajarkan menggunakan model pembelajaran konvensional.
\end{abstract}

\section{A B S T R A C T}

This research is aimed to know the difference of the science learning outcomes between students group who were taught by Self Regulated Learning (SRL) learning model and students group who were taught by conventional learning model. This research is a quasi experiment research that used Non Equivalent Post Test Only Control Group Design. The research population was all students of fifth grade in Gugus V, Buleleng Regency that consists of 163 students. The sample of the research was taken by random sampling technique. The sample that was chosen as experiment group was fifth grade students of SDN 2 Kaliuntu and the control group was SDN 3 Kaliuntu. The data of Science learning outcomes of the students were collected by test method in form of objective test. The data that were collected were analyzed by using analysis technique of descriptive statistics and inferential statistics (t-test) polled varians. Based on the results of hypothesis testing showed that there are significant differences in science learning outcomes between groups of students who follow the learning with Self Regulated Learning model and group of students who follow conventional learning. Test results obtained ( $t_{\text {observed }}=8.76>t_{\text {table }}=1.86$ ) so $H_{0}$ rejected and $H_{1}$ accepted. So that, the students group who were taught by Self Regulated Learning (SRL) learning model shows higher learning outcomes rather than students group who were taught by conventional learning model .

\footnotetext{
${ }^{1}$ Corresponding author.

E-mail addresses: ikadekadhidharmaputra@gmail.com (I Kadek Adhi Dharma Putra)
} 


\section{Pendahuluan}

Pendidikan merupakan salah satu kebutuhan manusia. Pendidikan merupakan investasi jangka panjang manusia yang memerlukan usaha dan biaya yang cukup besar. Jika tidak ada pendidikan, maka seorang manusia tidak akan mempunyai pengetahuan, sikap, dan keterampilan. Perlunya pengetahuan, sikap, dan keterampilan bagi seseorang adalah untuk kelangsungan masa depannya untuk dirinya sendiri dan juga orang lain. Pendidikan dewasa ini dikembangkan menuntut lebih ditekankannya pada pengetahuan, sikap, dan keterampilan seseorang. Pendidikan secara umum bertujuan menghasilkan sumber daya manusia yang berkualitas, cerdas, memiliki intelektual yang tinggi sehingga dapat mengisi kemerdekaan demi tercapainya tujuan pendidikan nasional (Juniayanti, 2016). Sekolah dasar merupakan jenjang pendidikan yang paling dasar dalam pendidikan formal. Dalam pendidikan sekolah dasar, siswa mulai mempelajari apa yang terjadi di dalam kehidupan sehari-hari. Dengan kata lain, materi pembelajaran yang diberikan dalam proses pembelajaran berkaitan dengan kehidupan siswa.

Menurut Dwicky (2015) Pembelajaran merupakan suatu cara untuk dapat merangsang, memelihara, dan meningkatkan terciptanya proses berpikir dan proses belajar individu untuk mengembangkan segala potensi dan kemampuan yang dimiliki dari setiap individu yang melalui proses belajar. Pembelajaran adalah suatu kombinasi yang tersusun meliputi unsur - unsur manusiawi, material, fasilitas, perlengkapan, dan prosedur yang saling mempengaruhi mencapai tujuan pembelajaran. Pembelajaran bertujuan untuk melatih dan mengembangkan potensi peserta didik melalui proses pengajaran dan latihan. Menurut Undang-Undang Sistem Pendidikan Nasional No. 20 Tahun 2003 menyatakan pembelajaran diartikan sebagai proses interaksi peserta didik dengan pendidik dan sumber belajar pada suatu lingkungan perolehan ilmu pengetahuan belajar. Menurut pengertian tersebut, pembelajaran merupakan bantuan yang diberikan pendidik agar terjadi proses perolehan ilmu dan pengetahuan, penguasaan, kemahiran, serta pembentukan sikap dan keyakinan peserta didik.

Wasliman (dalam Susanto, 2013:13) menyatakan bahwa pengelolaan pembelajaran yang berkualitas sangat menentukan keberhasilan proses pembelajaran di sekolah dasar. Upaya yang dapat dilakukan untuk meningkatkan pembelajaran yang berkualitas di sekolah dasar adalah dengan cara melaksanakan pembelajaran yang inovatif yang berpusat pada siswa. Hal ini sejalan dengan Permendikbud No. 22 Tahun 2016 menyatakan bahwa di dalam proses pembelajaran pada satuan pendidikan diselenggarakan secara interaktif, inspiratif, menyenangkan, menantang, memotivasi peserta didik untuk berpartisipasi aktif, serta memberikan ruang yang cukup bagi prakarsa, kreativitas, dan kemandirian sesuai dengan bakat, minat, dan perkembangan fisik serta psikologis peserta didik.

Menurut Undang-Undang Sistem Pendidikan Nasional No. 20 tahun 2003 pasal 37 ayat 1 menyatakan bahwa kurikulum pendidikan dasar dan menengah wajib memuat Ilmu Pengetahuan Alam. Pembelajaran yang inovatif harus ada dalam pembelajaran Ilmu Pengetahuan Alam (IPA). Pembelajaran IPA yang ideal menurut Depdiknas (2007) adalah 1) mampu menumbuhkan kepercayaan diri siswa dalam proses pembelajaram, 2) membelajarkan IPA disertai pengembangan sikap ilmiah, 3) mengembangkan kemampuan bernalar, merencanakan dan melakukan penyelidikan ilmiah, 4) merevitalisasi keterampilan proses sains bagi siswa, guru, dan calon guru. Riastini (2016:5) menyatakan, IPA memiliki tiga komponen yaitu, pertama proses ilmiah contohnya mengamati, mengklarifikasi, memprediksi, merancang, dan melaksanakan eksperimen, kedua produk ilmiah contohnya prinsip, konsep hukum, dan teori, ketiga sikap ilmiah contohnya seperti diskusi, penyelidikan, simulasi, kegiatan proyek, jujur, bertanggung jawab dan displin.

Berdasarkan kenyataan ketika dilakukan wawancara kepada siswa yang mendapat peringkat tiga teratas dan siswa yang mendapat peringkat tiga terbawah di kelas $\mathrm{V}$ pada masing-masing sekolah dasar yang ada di gugus X Kecamatan Buleleng dengan jumlah total interviewee yaitu 36 siswa. Hasil dari wawanacara adalah sebagai berikut, 24 siswa atau sekitar $66 \%$ menyatakan pembelajaran Ilmu Pengetahuan Alam kurang diminati karena siswa mengaku bosan dan mengantuk saat proses pembelajaran IPA disebabkan oleh guru yang sibuk sendiri menjelaskan materi pembelajaran, sedangkan 12 siswa atau sekitar 34\% mengaku senang dalam pembelajaran Ilmu Pengetahuan Alam disebabkan karena dalam pembelajaran Ilmu Pengetahuan Alam terdapat percobaan yang menurut siswa menyenangkan.

Setelah melakukan wawancara, dilanjutkan dengan kegiatan observasi guru ketika proses pembelajaran IPA kelas V di Gugus X Kecamatan Buleleng Hasil dari observasi adalah sebagai berikut. Pertama, ketika proses pembelajaran berlangsung guru mengajar dengan ceramah dalam menyampaikan materi pelajaran sehingga hanya berpusat pada guru, siswa hanya mencatat penjelasan dan menjawab soal-soal latihan yang ada di LKS siswa. Hal tersebut yang menyebabkan siswa merasa bosan, pasif dan mengantuk saat pembelajaran IPA serta antusias siswa dalam proses pembelajaran sangat kurang. Kedua 
kurangnya kesiapan siswa untuk menerima pembelajaran, ketiga guru kurang memanfaatkan alat peraga dalam proses pembelajaran.

Melengkapi hasil wawancara dan observasi, maka dilaksanakanlah pencatatan dokumen terhadap hasil belajar IPA kelas V SD Gugus X Kecamatan Buleleng. Berdasarkan hasil pencatatan dokumen diperoleh nilai Ulangan Akhir Semester (UAS) yang masih di bawah rata-rata KKM. Jumlah keseluruhan siswa kelas V semester I SD di Gugus X Kecamatan Buleleng tahun pelajaran 2017/2018 sebanyak 162 siswa dengan siswa yang belum mencapai KKM 42,60\%. Artinya bahwa, hasil belajar IPA siswa kelas V di SD Gugus X Kecamatan Buleleng tahun pelajaran 2017/2018 masih rendah.

Berdasarkan data yang diperoleh melalui wawancara, observasi dan pencatatan dokumen, maka diperlukan model pembelajaran baru yang dapat meningkatkan hasil belajar siswa dalam pelajaran IPA sehingga menjadi lebih optimal. Proses pengoptimalan yang dimaksud adalah memberikan kebermaknaan pada proses pembelajaran dan membuat siswa merasa bahwa merekalah yang mengelola proses pembelajarannya sendiri guna mencapai hasil belajar yang maksimal. Model pembelajaran yang dapat digunakan guru untuk membantu siswa mendapatkan hasil belajar yang maksimal adalah Model Self Regulated Learning.

Model Self Regulated Learning adalah model pembelajaran yang memberikan keleluasaan kepada siswa untuk mengolah secara efektif pembelajarannya sendiri dalam berbagai cara, sehinga mencapai hasil belajar yang optimal. Hal ini sejalan dengan pendapat Zimmerman \& Schunk (dalam Santyasa 2014:4) model pembelajaran Self Regulated Learning merupakan model pembelajaran dengan pengaturan diri yang dapat membuat siswa memiliki pengetahuan tentang strategi belajar yang efektif yang berakitan dengan pengetahuan dan kapan harus menggunakan pengetahuan tersebut.

Model SRL terdiri dari tujuh tahapan yaitu: (1) penganalisaan (analyse); (2) perencanaan (plan); (3) implementasi (implement); (4) pengamatan terhadap pemahaman (comprehend); (5) pemecahan masalah (problem solving); (6) evaluasi (evaluate); dan (7) modifikasi dan elaborasi (modify) Santyasa, (2014:3).

Self Regulated Learning juga memberikan kontribusi yang positif pada siswa yaitu: (1) siswa secara personal dapat meningkatkan kemampuannya untuk belajar melalui motivasi diri dan kepercayaan diri; (2) siswa secara proaktif dapat memilih struktur dan mengkreasikan lingkungan belajarnya yang meliputi aspek fisik dan non fisik yang menguntungkan untuk mencapai tujuan pembelajaran; dan (3) siswa dapat memainkan peran yang signifikan dalam memilih bentuk dan aktivitas belajar sesuai dengan kebutuhannya Santyasa, (2017: 183). Jadi, model Self Regulated Learning adalah model pembelajaran yang memberikan keleluasaan kepada pebelajar untuk mengelola secara efektif pembelajarannya sendiri dalam berbagai cara sehingga mencapai hasil belajar yang optimal, disamping itu model Self Regulated Learning memiliki tujuh langkah yang akan memberikan siswa peluang seluas-luasnya untuk berkreasi dalam mengelola pembelajarannya sendiri. Dengan demikian siswa akan termotivasi untuk belajar dan mengalami sendiri proses pembelajarannya sehingga menimbulkan kebermaknaan dalam proses belajar.

Berdasarkan uraian yang telah dipaparkan, model Self Regulated Learning memberikan pengaruh terhadap hasil belajar IPA. Namun besarnya pengaruh model pembelajaran Self Regulated Learning belum dapat diketahui maka dari itu dilakukan penelitiann yang berjudul "Pengaruh Model Self Regulated Learning Terhadap Hasil Belajar IPA Siswa Kelas V di Gugus X Kecamatan Buleleng Tahun Pelajaran 2017/2018".

\section{Metode}

Rancangan penelitian ini merupakan penelitian eksperimen semu. Rancangan penelitian ini menggunakan Non Equivalent Posttest Only Control Group Design. Populasi dalam penelitian ini, yaitu semua siswa kelas V di SD Gugus X yang berjumlah 5 sekolah dasar. Jumlah seluruh populasi adalah 162 siswa.

Setelah dilakukan uji kesetaraan, diperoleh hasil yaitu kelima populasi tersebut setara. Selanjutnya menentukan sampel penelitian dengan teknik random sampling (undian). Sampel yang terpilih adalah siswa kelas V di SDN 2 Kaliuntu yang berjumlah 19 siswa sebagai kelompok eksperimen mendapatkan perlakuan dengan model pembelajaran Self Regulated Learning dan siswa di SDN 3 Kaliuntu yang berjumlah 23 siswa sebagai kelompok kontrol yang mendapatkan perlakuan model pembelajaran konvensional.

Penelitian ini menyelidiki pengaruh satu variable terikat dan satu variable bebas. Variable bebas dalam penelitian ini, yaitu model pembelajaran yang terdiri dari dua jenis, yaitu: model pembelajaran Self Regulated Learning dan model pembelajaran konvensional. Variabel terikatnya, yaitu hasil belajar IPA. 
Hasil belajar IPA yang dimaksud adalah hasil yang diperoleh atau dicapai setelah mengalami proses belajar IPA. Dalam penelitian ini terbatas pada hasil belajar pada ranah kognitif yang diukur dengan menggunakan tes hasil belajar. Hasil pengukuran berupa data interval (skor).

Metode pengumpulan data yang digunakan untuk mengetahui hasil belajar siswa adalah metode tes. Tes yang digunakan adalah tes pilihan ganda (objektif) yang terdiri dari 30 soal. Tes ini mengungkapkan tentang penguasaan siswa terhadap pelajaran IPA yang telah mereka peroleh. Setiap item diberi skor 1 apabila siswa menjawab dengan benar dan siswa yang menjawab salah diberi skor 0 . Kemudian skor setiap item dijumlahkan dan jumlah tersebut merupakan skor variabel hasil belajar IPA. Skor 0 merupakan skor minimal ideal, sedangkan skor maksimal ideal adalah 30. Sebelum diuji coba, dilakukan uji expert judges terhadap instrumen hasil belajar yang dibuat.

Tahap selanjutnya melaksanakan uji coba instrumen. Data yang diperoleh dari uji coba instrumen dianalisis dengan menggunakan uji validitas butir tes, reliabilitas tes, daya beda tes, dan tingkat kesukaran tes. Analisis data pada penelitian ini, dilakukan dengan menggunakan bantuan program komputer Microsoft Office Excel 2007 for Windows.

Pengujian tes dilakukan kepada 75 siswa kelas VI di SD Gugus X Kecamatan Buleleng, sekolah yang dipilih yaitu SDN 1 Kaliuntu, SDN 2 Kaliuntu, dan SDN 3 Kaliuntu. Jumlah soal yang diuji coba berjumlah 40 butir tes berbentuk pilihan ganda. Tahap analisis pertama dilakukan uji validitas butir dengan

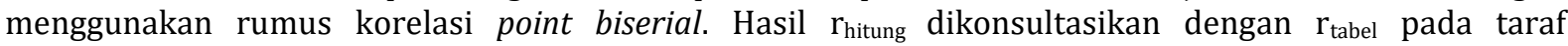
signifikansi $5 \%$. Jika nilai $r_{\text {hitung }}>r_{\text {tabel}}$, maka instrumen dinyatakan valid. Berdasarkan hasil analisis diperoleh hasil dari 40 butir soal yang diujicobakan diperoleh 30 butir tes yang valid dan 10 butir yang gugur. Instrumen hasil belajar IPA yang digunakan adalah soal dengan status butir valid dan untuk butir dengan status gugur tidak digunakan.

Tahap analisis kedua dilakukan uji reliabilitas tes pada 30 soal yang sudah valid, dengan menggunakan rumus Alpha Cronbach. Dalam penelitian ini, tes yang digunakan harus memiliki kriteria reliabilitas mulai dari sedang sampai sangat tinggi. Berdasarkan perhitungan, diperoleh reliabilitas tes hasil belajar IPA sebesar 0,96. Jadi reliabilitas tes berkualifikasi sangat tinggi.

Tahap analisis ketiga adalah mencari tingkat kesukaran tes. Taraf kesukaran perangkat tes yang digunakan harus memiliki kriteria sedang. Berdasarkan perhitungan diperoleh tingkat kesukaran perangkat tes sebesar 0,57, sehingga dapat disimpulkan bahwa butir-butir instrumen hasil belajar IPA memiliki tingkat kesukaran sedang.

Tahap analisis terakhir adalah mencari daya beda tes. Tes yang digunakan dalam penelitian harus memiliki kriteria daya beda mulai dari cukup baik sampai sangat baik. Berdasarkan perhitungan diperoleh daya beda perangkat tes sebesar 0,76, sehingga dapat disimpulkan bahwa butir-butir instrumen hasil belajar IPA memiliki daya beda yang sangat baik.

Metode analisis data yang digunakan adalah teknik analisis statistik deskriptif dan inferensial (ujit). Statistik deskriptif yang dicari adalah Mean (M), median (Md), Modus (Mo), standar deviasi, dan varians. Uji-t digunakan untuk menguji hipotesis penelitian. Rumus uji-t yang digunakan yaitu rumus polled varians dengan ketentuan, apabila $\mathrm{n}_{1 \neq} \mathrm{n}_{2}$ dan varians homogen, dengan $\mathrm{db}=\mathrm{n}_{1}+\mathrm{n}_{2}-2$.

Sebelum melaksanakan pengujian hipotesis, dilakukan uji prasyarat hipotesis. Uji prasyarat yang dilakukan adalah uji normalitas sebaran data dengan Chi-Square, kriteria pengujian data berdistribusi normal apabila $\hbar^{2}{ }_{\text {hitung }}<\hat{\lambda}_{\text {tabel }}^{2}$ dengan taraf signifikansi 5\% dan derajat (dk = jumlah kelas dikurangi parameter, dikurangi 1). Selanjutnya dilakukan uji homogenitas varians dengan Uji Fisher (F). Varians dikatakan homogen jika $\mathrm{F}_{\text {hitung }}<\mathrm{F}_{\text {tabel }}$ pada taraf signifikansi $5 \%$ dengan derajat kebebasan $(\mathrm{db})=\mathrm{n}_{1}-1$ untuk pembilang, dan $(\mathrm{db})=\mathrm{n}_{2}-1$ untuk penyebut.

\section{Hasil dan Pembahasan}

Distribusi frekuensi data hasil belajar IPA siswa kelompok eksperimen yang dibelajarkan dengan model pembelajaran Self Regulated Learning disajikan pada Gambar 1 berikut. 


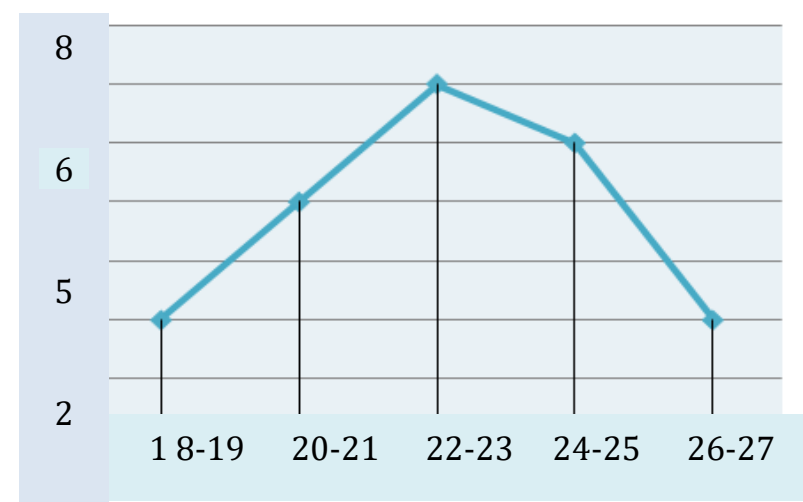

Gambar 1. Kurva Poligon Data Hasil Belajar Kelompok Eksperimen

Analisis data pada kelompok eksperimen menunjukkan bahwa, Modus = 23,9, Median = 22,9, Mean $(M)=22,7$. Dari grafik tersebut, tampak bahwa kurva sebaran data kelompok siswa yang mengikuti model pembelajaran Self Regulated Learning merupakan kurva juling negatif karena Mo $>$ Me $>$ M $(23,9>$ $22,9>22,7)$. Hal ini menunjukkan bahwa, sebagian besar skor siswa kelompok eksperimen cenderung tinggi. Untuk menentukan tinggi rendahnya hasil belajar IPA, skor rata-rata (mean) dikonversikan dengan menggunakan kriteria rata-rata ideal (Mi) dan standar deviasi ideal $\left(\mathrm{SD}_{\mathrm{i}}\right)$. Berdasarkan hasil analisis data, rata-rata hasil belajar IPA pada kelompok eksperimen yang menggunakan model pembelajaran Self Regulated Learning sebesar 22,7. Jika dikonversikan ke dalam PAP skala lima, maka berada pada kategori sangat tinggi. Dari gambar 2, tampak bahwa kurva sebaran data kelompok siswa yang mengikuti model pembelajaran konvensional merupakan juling positif karena $\mathrm{M}>\mathrm{Md}>\mathrm{Mo}(\mathrm{M}=15,52>\mathrm{Md}=14,36>\mathrm{Mo}=$ 13,9). Hal ini menunjukkan, bahwa sebagian besar skor siswa kelompok kontrol cenderung rendah.

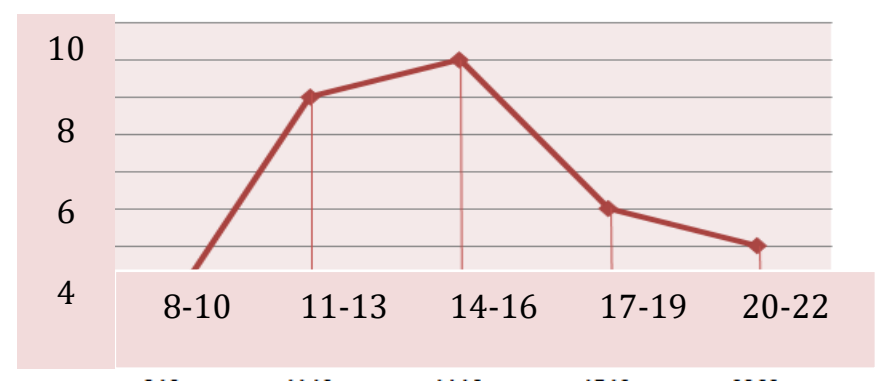

Gambar 2. Kurva Poligon Data Hasil Belajar Kelompok Kontrol

Berdasarkan hasil analisis data, diperoleh mean hasil belajar IPA kelompok kontrol sebesar 15,52. Jika dikonversikan ke dalam PAP Skala Lima nilai, maka berada pada kategori tinggi.

Selanjutnya dilakukan pengujian prasyarat hipotesis penelitian, yakni uji normalitas sebaran data dan homogenitas varians. Ringkasan hasil pengujian normalitas sebaran data disajikan pada Tabel 1 berikut.

Tabel 1. Ringkasan Uji Normalitas Sebaran Data

\begin{tabular}{llll}
\hline Kelompok & $\hbar^{2}$ tabel & $\hbar^{2}$ hitung & Keterangan \\
\hline Eksperimen & 5,59 & 0.730 & Normal \\
Kontrol & 5,59 & 5,035 & Normal \\
\hline
\end{tabular}

Berdasarkan Tabel 1 tersebut dapat disimpulkan sebagai berikut: Pengujian normalitas sebaran data kelompok siswa yang dibelajarkan dengan model pembelajaran Self Regulated Learning menunjukkan nilai $\lambda^{2}$ hitung sebesar 0.730, sedangkan $\lambda^{2}$ tabel sebesar 5,59. Berdasarkan nilai tersebut terbukti bahwa $\hbar^{2}$ hitung $<\hbar^{2}$ tabel Dengan demikian dapat disimpulkan, bahwa sebaran data hasil belajar IPA siswa pada kelompok eksperimen berdistribusi normal. 
Pengujian normalitas sebaran data hasil belajar IPA siswa pada kelompok yang dibelajarkan dengan model pembelajaran konvensional menunjukkan nilai $\lambda^{2}{ }_{\text {hitung }}$ sebesar 5,035 , sedangkan

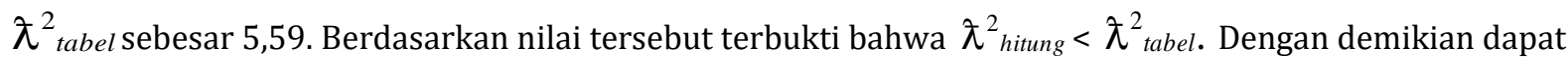
disimpulkan bahwa, sebaran data hasil belajar siswa pada kelompok kontrol berdistribusi normal. berikut.

Ringkasan hasil uji homogenitas varians data hasil belajar IPA siswa disajikan pada Tabel 2

Tabel 2. Hasil Uji Homogenitas Varians

\begin{tabular}{llll}
\hline Kelompok & $F_{\text {tabel }}$ & $F_{\text {hitung }}$ & Keterangan \\
\hline $\begin{array}{l}\text { Eksperimen } \\
\text { Kontrol }\end{array}$ & 2,1 & 1,87 & Homogen \\
\hline
\end{tabular}

Berdasarkan Tabel 2, diketahui $\mathrm{F}_{\text {hitung }}$ hasil belajar IPA siswa pada kelompok eksperimen dan kontrol sebesar 1,87. Sedangkan $\mathrm{F}_{\text {tabel }}$ dengan $\mathrm{db}_{\text {pembilang }}=23-1=22$, d $\mathrm{b}_{\text {penyebut }}=19-1=18$, pada taraf signifikansi 5\% sebesar 2,1. Berdasarkan nilai tersebut terbukti bahwa $F_{\text {hitung }}<F_{\text {tabel. }}$. Hal ini berarti, varians data hasil belajar IPA siswa pada kelompok eksperimen dan kontrol adalah homogen.

Berdasarkan hasil analisis uji prasyarat hipotesis, diperoleh bahwa data hasil belajar IPA siswa kelompok eksperimen dan kontrol adalah normal dan homogen, sehingga pengujian hipotesis penelitian dapat dilakukan dengan uji-t. Pengujian hipotesis penelitian menggunakan bantuan program komputer yakni, Microsoft Office Excel 2007 for Windows. Ringkasan hasil pengujian hipotesis penelitian disajikan pada Tabel 3 berikut.

Tabel 3. Hasil Pengujian Hipotesis

\begin{tabular}{lccccccc}
\hline Kelompok Belajar & Variian & $\mathbf{n}$ & $\mathbf{D b}$ & $\mathbf{t}_{\text {hitung }}$ & $\mathbf{t}_{\text {tabel }}$ & $\begin{array}{c}\text { Kesimpula } \\
\mathbf{n}\end{array}$ \\
\hline $\begin{array}{l}\text { Kelompok Eksperimen } \\
\text { Kelompok Kontrol }\end{array}$ & 5,783 & 19 & 4 & 8,76 & 6 & 1,8 & $\begin{array}{c}\mathrm{t}_{\text {hitung }}>\mathrm{t}_{\text {tabel }} \\
\text { H1 diterima }\end{array}$ \\
\hline
\end{tabular}

Tabel 3 menunjukkan bahwa, hasil perhitungan dengan uji-t mendapatkan $t_{\text {hitung }}$ sebesar 8,76, pada taraf signifikansi $5 \%$ dan $\mathrm{db}=40$, $\mathrm{t}_{\text {tabel }}$ diperoleh sebesar 1,86 . Ini berarti $\mathrm{t}_{\text {hitung }}>\mathrm{t}_{\text {tabel }}$, sehingga $\mathrm{H}_{0}$ ditolak dan $\mathrm{H}_{1}$ diterima. Dengan demikian dapat disimpulkan, bahwa terdapat perbedaan yang signifikan hasil belajar IPA antara kelompok siswa yang dibelajarkan dengan model pembelajaran Self Regulated Learning dan kelompok siswa yang dibelajarkan dengan model konvensional pada siswa kelas V di SD Gugus X Kecamatan Buleleng Tahun Pelajaran 2017/2018.

Secara umum, hasil penelitian ini menunjukkan bahwa terdapat perbedaan yang signifikan hasil belajar IPA antara kelompok siswa yang dibelajarkan dengan menggunakan model pembelajaran Self Regulated Learning dan kelompok siswa yang dibelajarkan menggunakan model konvensional. Hal ini dapat dIjelaskan dari hasil belajar IPA yang dicapai oleh siswa. Secara analisis deskriptif, hasil belajar IPA siswa pada kelompok eksperimen lebih tinggi dibandingkan dengan siswa pada kelompok kontrol. Ratarata skor hasil belajar IPA yang diperoleh siswa pada kelompok eksperimen sebesar 22,71 berada pada kategori sangat tinggi, sedangkan skor hasil belajar IPA yang diperoleh siswa pada kelompok kontrol sebesar 15,52 berada pada kategori tinggi. Perbedaan hasil belajar antara kelas siswa yang dibelajarkan menggunakan model Self Regulated Learning dengan kelompok siswa yang dibelajarkan dengan model pembelajaran konvensional disebabkan oleh beberapa hal yaitu sebagai berikut.

Pertama, kelompok siswa yang mengikuti pembelajaran menggunakan model Self Regulated Learning mendapatkan nilai belajar yang lebih baik karena secara teoretis, model Self Regulated Learning merupakan model pembelajaran yang berlandaskan kontruktivisme yang menempatkan siswa melakukan proses aktif dalam membangun pengetahuannya berdasarkan data, informasi, pengalaman dan pengetahuan yang telah dimiliki. Dengan demikian, proses pembelajaran lebih menekankan pada peran aktif siswa dalam pembelajaran untuk mengontruksi pengetahuan siswa secara mandiri sesuai dengan pengalaman, kemampuan dan tingkat perkembangan individual siswa. Hal tersebut sejalan dengan pendapat Gagne dan Marzano (dalam Santyasa 2017: 182) yang menyatakan bahwa "paradigma 
kontruktivisme dalam model pembelajaran Self Regulated Learning dirancang dan dikelola sedemikan rupa, sehingga mampu mendorong pebelajar untuk mengorganisasikan pemahamannya sendiri menjadi suatu pengetahuan baru yang bermakna". Sesuai dengan temuan penelitian yang dilaksanakan oleh Doni (2015:8) yang menyatakan bahwa "pembelajaran dengan model Self Regulated Learning pada tahapan analyze, siswa menganalisis materi pembelajaran serta menghubungkan materi yang terkait dengan pengetahuan awal siswa dengan hal tersebut terbukti membuat siswa lebih mudah memahami materi pembelajaran dan berdampak positif pada hasil belajar siswa". Dengan demikian hasil belajar siswa menjadi lebih optimal.

Kedua, temuan penelitian menunjukkan, bahwa pembelajaran menggunakan model Self Regulated Learning pada tahap problem solving (pemecahan masalah) secara langsung melatih siswa untuk percaya diri dalam menghadapi masalah dan menyelesaikan suatu permasalahan yang berkaitan dengan materi pembelajaran. Siswa yang dibelajarkan menggunakan model SRL berdasarkan tahapan-tahapan yang teratur. Tahapan dimulai dari Analyze (penganalisaan), Plan (perencanaan), Implement (implementasi), Comprehend (pengamatan terhadap pemahaman), Problem Solving (pemecahan masalah), Evaluate (evaluasi), Modifiy (modifikasi). Melalui tahapan-tahapan tersebut siswa diberikan peluang seluas-luasnya untuk berkreasi dalam mengelola pembelajarannya sendiri. Hal ini sesuai dengan teori yang dikemukakan oleh Santyasa (2017:182) menyatakan, "model Self Regulated Learning sebagai salah satu model pembelajaran yang memberikan keleluasaan kepada siswa untuk mengelola dan mengatur secara mandiri kegiatan pembelajarannya sehingga hal tersebut menjadi salah satu upaya dalam meningkatkan hasil belajar siswa". Selanjutnya, sesuai dengan temuan penelitian yang dilakukan oleh Wulandari (2017), hasil penelitian membuktikan "model Self Regulated Learning memberikan kebermaknaan dalam proses belajar disebabkan tahapan-tahapan pada model Self Regulated Learning membuat siswa termotivasi untuk belajar mandiri dan mengalami sendiri proses pembelajarannya sehingga menimbulkan kebermaknaan dalam belajar". Dengan demikian kebermaknaan dalam proses pembelajaran membuat materi pembelajaran lebih melekat diingatan siswa dan hasil belajar menjadi meningkat.

Ketiga, pembelajaran menggunakan model Self Regulated Learning adalah suatu proses yang membantu siswa dalam mengelola pikiran, prilaku, dan emosi agar mampu mengontrol pengalaman belajarnya. Regulasi diri dalam proses pembelajaran bermakna spesifik, yakni siswa diberikan kebebasan untuk mengelola sendiri kegiatan pembelajaran mulai dari tahap perencanaan, penerapan, dan evaluasi dengan demikian siswa akan mengetahui kekurangan dan kelebihan yang dimiliki selama proses pembelajaran. Hal ini sesuai dengan teori yang dikemukakan Woofolk (2008) "siswa yang belajar dengan regulasi diri bukan hanya belajar tentang materi pembelajaran tetapi siswa juga belajar untuk menyesuaaikan kondisi belajar, mengatur tingkah laku dan menerapkan strategi pembelajaran yang fleksibel dalam belajar". Selanjutnya, sesuai dengan temuan penelitian yang dilakukan Aftina (2014:59), "regulasi diri dalam proses pembelajaran membuat siswa aktif dalam mengelola pembelajaran, mengatasi hambatan-hambatan internal dan eksternal, mengetahui hal-hal yang belum dicapai dalam proses belajar dan mampu menyesuaikan diri dengan lingkungan belajar, serta siswa memiliki tekad untuk mencapai hasil belajar yang diharapkan". Artinya dengan regulasi diri dalam proses pembelajaran siswa mampu untuk mengatur kegiatan belajarnya serta memiliki kesadaran diri atas potensi yang dimiliki dan dapat menggunakannya dengan baik guna mencapai hasil belajar yang optimal.

Model Self Regulated Learning memberikan dampak positif kepada siswa yaitu siswa menjadi lebih aktif, percaya diri dalam menghadapi masalah dan mampu mengontrol diri dalam proses pembelajaran guna meningkatkan hasil belajar IPA. Penerapan model Self Regulated Learning menimbulkan konsekuensi logis yaitu siswa lebih tertantang dalam meningkatkan hasil belajarnya dengan cara berlatih latihan soal-soal tentang pemecahan masalah IPA, belajar dengan cara berkelompok, belajar dengan tutor, dan mencari sumber belajar lainnya selain yang ada di sekolah seperti internet maupun youtube. Bagi guru dengan menerapkan model Self Regulated Learning guru memperoleh pengalaman baru dalam menerapkan model inovatif di kelas, sehingga dapat diterapkan pada pelajaran lainnya. Penerapan model Self Regulated Learning menimbulkan konsekuensi logis bagi guru. Guru hendaknya memperkaya wawasan dan lebih tertantang untuk mencari referensi baru, mengeksplor dan memperluas pengetahuan mengenai model pembelajaran inovatif lainnya. Salah satunya yaitu dengan cara mengikuti KKG, workshop dan mengikuti pelatihan lainnya sehingga guru dapat melakukan pembaharuan yang dapat memperbaiki dan meningkatkan kualitas pembelajaran di kelas. Penerapan model Self Regulated Learning menimbulkan konsekuensi logis bagi sekolah yaitu sekolah hendaknya dapat menyediakan fasilitasfasilitas pendukung pembelajaran berupa pengadaan alat peraga/media yang menunjang kegiatan pembelajaran dan perpustakaan dengan buku-buku ajar yang lebih relevan dalam mendukung materi pembelajaran sehingga dapat digunakan oleh siswa maupun guru dalam proses pembelajaran. 


\section{Simpulan dan Saran}

Berdasarkan hasil penelitian yang dilakukann di SD Gugus X Kecamatan Buleleng Tahun Pelajaran 2017/2018 dapat disimpulkan bahwa terdapat perbedaan yang signifikan hasil belajar IPA antara kelompok siswa yang dibelajarkan dengan model Self Regulated Learning dan kelompok siswa yang dibelajarkan model konvensional. Hal ini dapa dilihat pada penghitungan uji-t, diperoleh thitung sebesar 8,76, sedangkan, tabel dengan $\mathrm{db}=40$ dan taraf signifikansi $5 \%$ adalah 1,86. Hal ini berarti, $\mathrm{t}_{\text {hit }}$ lebih besar daripada $t_{\text {tab }}\left(t_{\text {hit }}>t_{\text {tab }}\right.$ ), sehingga $\mathrm{H}_{0}$ ditolak dan $\mathrm{H}_{1}$ diterima. Hasil penghitungan tersebut menunjukan bahwa $\mathrm{t}_{\text {hitung }}>\mathrm{t}_{\text {tabel. }}$. Sehingga $\mathrm{H}_{0}$ ditolak dan $\mathrm{H}_{1}$ diterima. Rata-rata nilai hasil belajar kelompok siswa yang mengikui model Self Regulated Learning adalah 22,71 berada pada kategori sangat tinggi, sedangkan skor hasil belajar IPA yang diperoleh siswa yang dibelajarkan model pembelajaran konvensional sebesar 15,52 berada pada kategori tinggi. Adanya perbedaan yang signifikan menunjukkan bahwa model Self Regulated Learning berpengaruh terhadap hasil belajar IPA pada siswa kelas V SD di Gugus X Kecamatan Buleleng Tahun Pelajaran 2017/ 2018.

Adapun saran yang dapat disimpulkan berdasarkan penelitian yang telah dilakukan yaitu pertama, Guru di sekolah dasar agar lebih berinovasi dalam menerapkan model pembelajaran inovatif lainnya, termasuk menerapkan pembelajaran dengan model Self Regulated learning sehingga meningkakan aktivitas siswa di dalam proses pembelajaran dan hasil belajar siswa menjadi lebih baik. Kedua, sekolah yang mengalami permasalahan mengenai hasil belajar IPA dapat mengambil suatu pertimbangan/kebijakan untuk mengimplementasikan model Self Regulated learning dalam pembelajaran IPA. Ketiga, peneliti lain hendaknya dapat menggunakan hasil penelitian ini sebagai bahan pertimbangan dan masukkan sebagai acuan untuk mengembangkan penelitian berikutnya.

\section{Daftar Rujukan}

Aftina, N H., Freida N R H dan Jati A. Regulasi Diri Mahasiswa Berprestasi. Jurnal Psikologi Undip. 13 (1) : 50-63.

Tersedia

pada

https:/eprints.undip.ac.id/51616/1/.Regulasi_diri_mawapres_Vol_13_No_1_Apr_2014.pdf. Diakses pada 27 Mei 2018

Agung, A.A. Gede. 2014. Metodologi Penelitian Pendidikan. Yogyakarta: Aditya Media Publishing

Arikunto, Suharsimi. 2005. Dasar-dasar Evaluasi Pendidikan. Yogyakarta: Bumi Aksara.

BSNP. 2007. Peraturan Menteri Pendidikan Nasional Republik Indonesia Nomor 41 Tahun 2007 Tentang Standar Proses untuk Satuan Pendidikan Dasar Dan Menengah. Jakarta: Badan Standar Nasional Pendidikan.

Candiasa, I Made. 2011. Pengujian Instrumen Penelitian Desertasi Aplikasi ITEMA dan BIGSTEP. Singaraja Press,

Depdiknas. 2007. Naskah Akademik Kajian Kebijakan Kurikulum Mata Pelajaran IPA. Jakarta: Pusat Kurikulum Badan Penelitian dan Pengembangan Depdiknas.

Doni, I N., Agung A.A., dan Antari, N N M. Pengaruh Self Regulated Learning Terhadap Sikap Spiritual dan Hasil Belajar PKn. E-Journal PGSD Universitas Pendidikan Ganesha. 3 (1) : 1-10. Tersedia Pada https://www.google.com/searchqpengaruh.model.self.regulatd_learning\&ie=utf-8\&oe=utf8\&client=firefox. Diakses pada 6 Februari 2018.

Dwicky.P.N. Dw.Md., A.A.Gede Agung, Ni.Ngh.Madri.A. 2015. Pengaruh Model Pembelajaran Self Regulated Learning (SRL) terhadap Sikap Ilmiah dan Hasil Belajar IPA Siswa Kelas IV Tahun Pelajaran 2014/2015 di Gugus XIII Kecamatan Buleleng. e-Journal PGSD Universitas Pendidikan Ganesha Jurusan PGSD Volume: 3 No: 1 Hal. 1-11. Tersedia Pada: https://ejournal.undiksha.ac.id/index.php/JJPGSD/article/view/5664/4122.

Juniayanti, Dewi, Gede Sedanayasa, I Gede Margunayasa. 2016. Pengaruh Model Pembelajaran Self Regulated Learning Berbantuan Media Lingkungan terhadap Motivasi Belajar IPA Siswa SD. eJournal PGSD Universitas Pendidikan Ganesha Jurusan PGSD Vol: 4 No: 1 Hal.1-9. Tersedia Pada: https://ejournal.undiksha.ac.id/index.php/JJPGSD/article/view/6956. 
Koyan, I W. 2011. Asessmen dalam Pendidikan. Singaraja: Universitas Pendidikan Ganesha Press.

Koyan, I W. 2012. Statistik Pendidikan Teknik Analisis Data Kuantitaif. Undiksha Press.

Riastini, N.P. 2016. Pembelajaran IPA SD. Singaraja: Undiksha Press.

Santyasa, I W. 2012. Seri Buku Ajar Perguruan TinggiPembelajaran Inovatif. :SingarajaUndiksha Press.

Santyasa, I W. 2014. Model Self Regulated Learning. Singaraja: Undiksha Press.

Santyasa, I W. 2017. Pembelajaran Inovatif. Singaraja: Undiksha Press.

Susanto, Ahmad. 2013. Teori Belajar dan Pembelajaran. Jakarta. Kencana Prenada media Group.

Undang-Undang Nomor 20 Tahun 2003 tentang Sistem Pendidikan Nasional (2003:2-3) Jakarta.Presiden Republik Indonesia.

Peraturan Menteri Pendidikan dan Kebudayaan Republik Indonesia (Permendikbud) Nomor 22 Tahun 2016 Tentang Standar Proses Pendidikan Dasar dann Menengah. Jakarta: Badan Standar Nasional Pendidikan.

Wulandari, L. P. E., Suarjana I.M., \& Riastini, P. N. 2017. Pengaruh Model Pembelajaran Self Regulated Learning (SRL) Berbantuan Media Video Pembelajaran terhadap Hasil Belajar IPA Siswa Kelas V. EJournal PGSD Universitas Pendidikan Ganesha. 5(2): 1-9. Tersedia pada https://ejournal.undiksha.ac.id/index.php/JJPGSD/article/view/11027. Diakses pada tanggal 30 Desember 2017.

Woofolk. 2008. Educational Psychology. Active Learning Edition Tenth Edition. Boston:Ally \& Bacon. 